\title{
Impacts of IoT and big data to automotive industry
}

\begin{abstract}
With the recent advancement in technologies such as embedded system, wireless distributed sensor, light weight material, smart cognitive radio networks, cloud computing, higher efficiency and ultra-low emission internal combustion engines, intelligent converter, high performance battery and fuel cell technology, the production of smarter, safer, energy efficient and zero emission vehicles is possible in near future. Apart from vehicle technologies, other factors such as road users', well maintained road infrastructure, well maintained vehicles, drivers' attitudes and law and enforcement are also important to be considered and they should work together in order to make our world natural resources can be preserved and maintain cleaner environment and produce sustainable mobility. This paper will discuss the impacts of IoT and Big Data and other emerging technologies mentioned above to the automotive industry. It will include discussion on education, economy, advanced technology, environment, safety and energy.
\end{abstract}

Keyword: Automotive industry; Big data; Cloud computing; Intelligent vehicle; IoT 